\title{
Congressional Investigations:
}

\section{THE LEGISLATOR AND HIS ENVIRONMENT}

\author{
EDWARD A. SHITS $\uparrow$
}

$\mathrm{C}$ ONGRESSIONAL investigating committees have brought about valuable reforms in American life. They have performed services which no other branch of the government and no private body could have accomplished. They have also-like any useful institutionbeen guilty of abuses. Like many institutional abuses, these have been products of the accentuation of certain features which have frequently contributed to the effectiveness of the investigative committee. In the following essay, we shall not concern ourselves with the description of these abuses, nor with the ways in which certain valuable practices, when pushed to an extreme, have become abuses. These abuses have included intrusions in spheres beyond the committees' terms of reference, excessive clamor for publicity, intemperate disrespect for the rights of witnesses, indiscriminate pursuit of evidence, sponsorship of injudicious and lighthearted accusations, disregard for the requirements of decorum in governmental institutions, and the use of incompetent and unscrupulous field investigators. * Here we shall take as our task the exploration of factors which may assist in understanding some of these peculiarities and excesses of congressional investigations.

In the view here taken these excesses arise out of the conditions of life of the American legislator: the American constitutional system itself, the vicissitudes of the political career in America, the status of the politician, the American social structure and a variety of other factors. This analysis does not claim to be a complete picture of the social pattern of the American legislator; it is not intended to be an exhaustive analysis. It seeks only to point out those factors which have produced certain features of the investigative process-especially the tone of acrimony, of hostility toward witnesses and of disregard for the standards of propriety and respect which are even more necessary in political democracies than in other systems of government.

$\dagger$ Professor of Social Science, Committee on Social Thought, University of Chicago.

* Consult Galloway, Proposed Reforms, page 478 supra; Carr, The Un-American Activities Committee, page 598 infra. 
We shall accordingly begin with an exposition of some of the sources of strain on the legislator. Then we shall go further into the manner in which these strains become intensified in the relations between politicians on the one hand and administrators, intellectuals, and, occasionally, business men on the other.

\section{I}

In the United States as in any other large democratic government, the burden on the legislator is great. The volume of legislation is vast and its complexity beyond the judgment of laymen. Even an expert could not hope to understand and master fully all the bills which are produced. This is particularly true in the United States where many bills are produced on the same subject and where individual legislators often have their own legislative ambitions, in addition to the program of their party leaders. The legislator is overwhelmed by his legislative work alone, the amount aggravating the difficulty. He frequently votes on measures on which he has not formed his own judgment and on which he has not had his judgment authoritatively and reassuringly formed for him by his party organization. The fact that he leaves so much uncovered has a disquieting effect on him; it causes him to feel that matters are slipping beyond his control.

The structure of the American party system and its manifestation in Congress accentuate the strains on the American legislator. $\mathrm{He}$ is very much on his own. The national party does not arrange his candidacy; it has little control over the machine on which the congressman depends for his re-election; and its financial aid for the conduct of his campaign is much less than adequate. He must keep his machine going. Like an ambassador who is uneasy that his enemies at home are undoing his work and undermining his position while he is away, the legislator must always keep his eye on the machine at home-fearing that it might break out of his control during his absence in Washington.

American constituents, at least a sector of them, are often very outspoken in their demands. The American legislator is moreover hypersensitive to the faintest whisper of a constituent's voice. Unable to depend on the national party for re-election, he must cultivate and nurture his constituency more than legislators in other democratic countries where constituents are less clamorous and parties are stronger at the center.

To satisfy the demands of some of his constituents the American legislator wastes his time and energy running errands for them in Washington and receiving them when they visit the capital for business or for sight- 
seeing purposes. He himself is often quite pleased to have this opportunity for personal contact with his constituents even though it distracts him from his job in Washington.

In addition to trying to please those whom he sees, he is constantly harried in his mind's eye by those whom he does not see or from whom he does not hear. His remoteness from them does not make him less sensitive to their sentiments or fearful of their displeasure. The distance from the voter and his anonymity make the sensitivity even greater and more delicate. The nature of the recruitment process favors the man with a delicate ear for the voters' sentiments, and an eagerness to gain their approbation; American politics favors the person who can present himself as a man of the people, who is proud that he deviates from them in no significant way and who fears that any known deviations would be interpreted as snobbery or stand-offishness.

This eagerness to gratify an unseen constituency and to rank high in their favor helps us to understand why it is that legislators who have no strong convictions on a given topic might sometimes be among its most fervent investigators. They do so simply because they believe it will appeal to their constituents and because they cannot allow any rival for the affection and votes of their constituents to pre-empt this theme.

Far from his home base and insecure about his tenure and support, he is hard put to find a procedure for keeping in touch with his constituents and fixing himself in their minds. The congressional investigation is often just the instrument which the legislator needs in order to remind his constituents of his existence. That is the reason why investigations often involve such unseemly uses of the organs of publicity. Publicity is the next best thing to the personal contact which the legislator must forego. It is his substitute offering by which he tries to counteract the personal contact which his rivals at home have with the constituents.

The frequent recourse to personal intervention on behalf of individual constituents has greater consequences than the maintenance of a sensitive attachment of the legislator to his audible constituency and the wasteful expenditure of his time. It fosters in him a particular attitude of personal expectancy toward the bureaucracy and towards the individual administrator.

The American legislator, whose professional traditions date back to a social order in which government intervention played no great part and in which patronage was the main method of recruitment, tends to look on the administrator's tasks as something which is properly his own responsibility-as something which is only transitorily delegated to the ad- 
ministrator. He draws no fine line between legislation and administration and he likes to co-operate in and assist in administration as well as to specify the administrator's tasks and powers. The modern separation of powers is indeed often felt as an implicit rebuff.

To these particular strains in the vocational life of an American legislator should be added the more general strains. For one thing the career of the professional politician is full of hazards. In all democracies the legislator is recurrently in danger of not being re-elected. In the event of being unsuccessful he must go back to a career which he has neglected. In the United States very few of our professional politicians are recruited from the classes which live from inherited wealth. If he is in the professions or in business he will have to make up the distance which his contemporaries have gained on him. Although he might have improved certain "connections," some of his skill other than political skill might well have deteriorated. Whatever the effect on his skill he faces the humiliation of return as a political failure, and the need to begin at a lower level than those who were his equals a few years before. Moreover, since our politicians do not come from classes which have as part of their tradition a normal expectation of entering a political career, they tend to a greater extent to be selected from among persons who enjoy the game of politics, to whom it has a special psychological appeal. For such persons, the threat of exclusion from politics through failure is especially menacing. Thus the situation of the political career in the United States makes legislators faced with the possibility of failure take eager refuge in devices which will recommend them to their constituents. Well publicized activity as a member of an investigative committee is one of these devices.

Even when successful, however, the professional politician in the United States cannot always have the pleasure and comfort of feeling that he is participating in a highly honored profession. The fact that he is so often made into an errand boy or a handmaiden to his constituents is indicative of their attitude towards him and of his attitude towards himself. Government in the United States, where established institutions are not usually objects of deep reverence, is far from the most esteemed of institutions. Living off the public treasury, from the taxpayers' money, whether as legislator or administrator, has until recently been rather looked down upon by the hard-working taxpayer and his newspaper spokesmen. This view is still at work in American public opinion. The image of the politician in the organs of mass communication is not a laudatory one. Pomposity, vanity, an unbalanced sense of importance and occasionally sheer dishonesty are 
part of the traditional American conception of the professional politician -although the reality has been far different. Even though this popular image has been changing in the past decades, the term "politician" still has a derogatory overtone. The occasional outbursts of an excessive desire to please on the one hand and of vindictive aggressiveness on the other are both products of this perception by the professional politician of his ambiguous status. The legislator's suspicion of the administrator as one who lives wastefully on the taxpayers' money is also an expression of his discomfiture concerning his own ambiguous status.

Congressional investigations often provide favorable occasions for the manifestation of this deep-lying distrust. It is not only the social status of politics that influences the legislator's mood. The geographical location of the center of national political life also has its effect. The almost exclusive position of politics as the chief employment of Washington has an influence on the life of the legislator. It means that he is forced to live almost entirely in an atmosphere of politics. It is true of course that many enjoy this type of life with its incessant stress on influence, rivalry, ambition and frustration-it sharpens political wits and has a brilliance of its own. It does however strengthen and even overdevelop the political orientation of men who have already entered voluntarily upon such a career. By political orientation is meant that exclusive preoccupation with political events to the point where every human activity becomes evaluated not in terms of its intrinsic value but in terms of its political significance. In Washington legislators must associate in their leisure hours almost entirely with other legislators or with journalists, administrators, and business men whose presence in Washington is almost always evidence of their own predominantly political interests. In such a society where the talk is invariably centered about who is getting what from whom, both the sensitivity and the insecurity of the legislator are increased. It strengthens his tendency to interpret everything in political terms and to look on the world as engaged at every moment in arranging political combinations, intended to advance some individual or group and to ruin another. This type of social life offers no respite from the tensions and anxieties of the individual legislator's own political career-it provides a stimulant rather than a soothing calm. The gossip and rumors agitate him and cause him to worry more about his own political fortunes. Hearing so much of what others are doing or are having done for them to secure their political fortunes, he feels he must exert himself more to establish and advance his own prestige. Whoever blocks him is his enemy. Whoever has a deficiency, real or imputable, which can be attacked in the name of a major 
political value, becomes a fair target in the competition to keep oneself politically afloat.

As a result of these factors-not all of which operate equally for all our legislators-the life of the American politician holding a seat in the Senate or in the House of Representatives is far from an easy one. He is always confronted with more demands on him than he can satisfy; he is always in danger of displeasing someone and he is never sure of just what it will take to please them or how he can do it when he knows what it is; he is always dependent on someone else's judgment for his equanimity and for his security. The result is a state of stress and disquiet, often flaring up into rage and sometimes into vindictiveness.

The emotional moods and the deeper attitudes to which they become fixed enter very intimately into the conduct of congressional investigations. The chief victims of congressional investigation are administrative officials and political dissenters, with big business men occasionally emerging as targets. We shall now deal with them in that order.

\section{II}

The traditions of the American Congress and the outlook of our congressmen are the products of a free society in which it was neither necessary nor desirable that large powers be assigned to the executive branch of the government. The inevitability of the delegation of power is often intellectually acknowledged by our legislators but there is also resentment against this necessity and a deep unwillingness to accept it. As we have already indicated, the bureaucrat or the administrator is regarded as the usurping rival of the legislator. General laws, when implemented in detail by administrators, often work hardships on particular constituents. The legislator is often unable to persuade the administrator to remove that hardship. In many cases the derogation of his power and status which this implies is bitterly felt by the legislator and animosity against particular administrators and against the executive branch and bureaucracy in general is fostered.

This attitude is also affected by the gradual diminution of the patronage system in the recruitment of the federal civil service. A civil servant appointed by patronage is the creature of the legislator. The prevailing atmosphere of the American political system, despite the establishment of the merit system in the federal civil service, is still that of patronage. The important role in the national parties of local and state "machines," subsisting on patronage, is responsible for this. A legislator who has passed through the lower levels of the party on his way upward still tends to 
expect civil servants to respond to him as though they are personally beholden to him. The fact that this is not so is well appreciated by the ordinary administrator and manifested in his behavior.

The contact between legislators and administrators who appear before the various standing committees and subcommittees is often frustrating to the legislator. There is seldom the element of direct challenge to the personal status of the legislator but the authoritative and self-assured way in which the administrator disposes of his own knowledge and the legislator's questions can also become a source of uneasiness. The administrator deals self-confidently with a matter which the legislator does not always grasp with the same measure of self-confidence. When the subject matter of the hearings is one about which the legislator already has some grievances, the result is apt to be a further rankling of his sentiments. The resulting "soreness" occasionally reveals itself in the support and conduct of investigations directed against the particular administrator and against bureaucrats in general.

This particular friction is, in part, one of the by-products of the merit system. The civil servant, particularly the civil servant of the level called before congressional committees, tends to be considerably more educated and probably of a higher social and economic status as regards his origin, than the legislator who is requesting a service of him or interrogating him. He is as we have indicated not only more expert in the matter at hand but he usually, either wittingly or unwittingly, is also more the master of the situation than the legislator. Resentment against those whose fortunate accidents of birth gave them educational opportunities which were not available to the legislator is heightened-it certainly was heightened during the Roosevelt administration-by an attitude of personal, social and intellectual superiority on the part of the administrator. This sense of superiority very often does not exist at all but is nonetheless often assumed to exist and is as bitterly resented.

The concurrent elevation of the educational level of the civil service and the delegation of vast legislative powers to a resourceful and ingenious executive only reinforced a difficulty which is endemic in the American constitutional system-namely, the sharp, personal separation of the legislative and executive branches. The fact that the leaders of the executive branch-the President to some extent, and even more, his cabinet members (except generally the relatively insignificant Postmaster General)-cannot usually be regarded as "one of the boys" deepens the breach between the legislators and the executive branch. It increases the likelihood of misunderstandings which accumulate and which cannot 
easily be cleared up by informal personal interchange, or prevented by the existence of close personal relations or friendship.

Some of these frictions are in the nature of our constitutional situation. If legislators are intended to watch over the execution of the laws they pass and to scrutinize the laws recommended to them by the executive branch, some friction will necessarily exist. It is however exaggerated by the adventitious element of the legislator's representation of the private interests of particular constituents. It is also driven further by the fact that except for personal intercessions and questioning in committees, the American legislator has no control over what he regards as injustices or inefficiencies in the working of the administrative system. He must intervene personally, often at the cost of much time and energy, or he must attempt to hold up the appropriation of an entire section of the administration. If he fails in the first and the second alternative is not available to him, he has only the investigative committee left to him. It is certainly not always easy to start such a committee and a long accumulation of hurts and grievances will usually have been felt before the committee can be created and got under way. He must wait until enough other legislators think the issue is a good one or until, for some other reason, enough other legislators are willing to allow him to go ahead. The long period of waiting and the gradual fusion of resentments from a great variety of sources make it more likely that the investigation will be rough. Even if he is not on the committee himself, he will often support it because it is a vicarious way of soothing the many hurts he has experienced. There is little opportunity for the release of pressure by moderate means, such as the question period in the House of Commons, which provides a regular opportunity for the airing of small injustices and prevents an accumulation first of personal animosity and then of animosity in general.* The possibility of having a particular wrong corrected imposes a sense of responsibility on the person who is trying to bring about the correction. If the situation has been allowed to go so far that accusations are generalized and no immediate corrections expectedwhen the legislator feels that he is shouting into the wind-then his accusations will become louder and angrier and his wrath will be less easily and efficiently appeased. Yet this is the atmosphere in which investigations are too often launched.

The strains which arise from our constitutional system and our cultural background are aggravated during periods of strong executive leadership and expansion of the executive. Strong executive leadership appears,

${ }^{*}$ Consult Finer, The British System, page 52I supra. 
while it is in operation, to cure the ailments, but under our present conditions it nonetheless leads inevitably to aggravation. The dry fruit of this aggravation is harvested in the period of weakest leadership. And jealous though they are of their powers and prerogatives, legislators normally renounce some of them during periods of national crisis. This was what happened under the administration of Franklin Roosevelt. His brilliant personality and self-confidence in confronting the domestic crisis of the thirties and the succeeding international crisis encouraged as great a delegation of power as any American Congress has ever participated in. Legislative regret and resentment over this delegation was already gathering force in the late I930's. Pressure accumulated because of the insolence and brilliance of the exceptional group of energetic administrators and advisors whom the President gathered round him. The demand for a redress of the balance-for revenge against the disrespectful usurpersgrew through the thirties and was scarcely held in check by the continuation of the crisis and the exceptional personal and political capacities of the late President. His replacement by Mr. Truman and the renaissance of demands for normality after the war released the flood of resentment which had been storing up against the chief executive and against the bureaucrats.

\section{III}

The animus of the legislator against the bureaucrat is fed further by another cleavage in American life. We refer here to the tension between intellectuals and politicians. Although this country, more than any other, owes its origins as a state to intellectuals, ever since the Jacksonian revolution there has been a distrust of intellectuals in politics and a distrust of politics among intellectuals. For nearly one hundred years the intellectuals of this country were identified with the genteel tradition-a tradition which stood in conflict with the rough-handed politics of the big city machines, and particularly with the urban, predominantly immigrant working classes of the big cities and the dour, commercially minded farmers of the Middle West. They stood apart too from the energetic capitalistic enterprisers of the great periods of economic expansion which followed the Civil and First World Wars. Academic intellectuals inspired by Germany and Great Britain had contributed greatly to the establishment of the merit system in the federal civil service. In many other contexts their estangement from the prevailing modes of activity of the "hail fellow well met" politician was evident. Those who lived in the light of the genteel tradition identified themselves with a cultural 
pattern which was waning. In doing so a large section of the American intellectual classes found themselves in opposition to most of the prospering tendencies in American life; they felt a stronger kinship with European cultural standards and practices and with sections of the population of the Eastern seaboard-the Eastern "aristocracy"-which felt an inner sympathy with the British pattern of life.

This attitude was by no means universal among the intellectuals. There was already much intellectual hostility towards the genteel tradition before the First World War, and afterward the flood engulfed it. Nonetheless the intellectual liberalism which drew its inspiration from Veblen, Dewey and Mencken and which opposed the genteel tradition was at least as antagonistic towards politics and politicians as the intellectuals whom they criticized. Although with the exception of Mencken and a few of the literary men, these critics of American politics were not admirers of European institutions, their critical attitude towards America and their sympathy with the socialistic aspects of the Russian Revolution made it easy for those who regarded themselves as the chief incorporation of American values to label the critics as un-American. This latter view was common among many politicians long before the Roosevelt administration.

The r930's saw the entry of the "intellectuals" into the government on an unprecedentedly large scale, and at an unprecedentedly rapid rate. The shock to the legislator of the loss of his power to the bureaucracy was certainly not rendered easier to bear by the fact that it was being surrendered to the intelligentsia. It was as if two enemies combined to become a single enemy; the hostility previously directed against the separate enemies now fused on the single object. This has been another element in the acerbity of congressional investigations.

Still other strands in this thread of legislative hostility have been a pervasive and peculiar form of xenophobia and the fear of the consequences of disloyalty. We shall deal first with the former. Although the proportion of foreign-born persons in the United States has dwindled greatly in the past quarter-century, concern over imperfect assimilation is still strong on both sides of the line. It is strong both among the more assimilated and less assimilated. Both proclaim the successful achievement of their Americanization, and the deficiencies of those who are less Americanized. It is natural for human beings who are uncertain of their own conformity with a given standard to abuse others for inadequate conformity with it. The United States is a country which has undergone rapid changes; it is loose in its attachment to most traditions except 
those of individual freedom and reverence for the Constitution. Americans are relatively unbound by professsional and occupational ties and by local loyalties. When we are uncertain about the genuineness of our loyalties, we tend to suspect others of not being genuine in their loyalties. When our loyalties are loosely anchored to particular places and institutions, we sometimes feel the need to be loyal more urgently than do those persons and societies which are more firmly established in traditional loyalties. The very looseness of our loyalties, which on the one hand is a condition of our freedom, makes us on the other hand more sensitive about our loyalties. Periods of crisis make men feel the need for protection; they also make them need to feel loyal to some powerful protective institution such as a mighty national state. The less they are bound by professional and local loyalties, the more will they feel the need for the more inclusive loyalty, and the more suspicious will they be of the genuineness and sufficiency of the loyalty of others. The weakness of the former type of loyalty will strengthen the disposition to think in terms of crisis, to interpret situations as if they were crises. Mobile, traditionless people will be quicker to see and proclaim a crisis than those whose professional and local loyalties hold them fast.

In the United States politicians have an unusually high degree of social mobility. Politicians, more than any other profession, represent the realization of the idea of the poor boy who takes advantage of the opportunities of an open society and rises to the top. Even more than business men and intellectuals, American politicians have moved from the society of their birth and youth. They have moved from their earlier residences to Washington where they live away from their old friends and associates. They have given up their earlier occupation and as we have already said, they live in a world full of pitfalls and threats to their professional success. Many of them are, in the old term, "hyphenates" of fairly recent generations, and would like to live it down. The one firm foundation of their faith is therefore America and all which threatens them is interpreted as a threat to America. There is in consequence a general suspicion among legislators of disloyalty to American standards, of unAmericanism, on the part of those who deviate from them in other respects. Those who challenge them and make them uneasy-bureaucrats and intellectuals - are therewith cast outside the circle of the saved, at least until they have been cleared. The vague and troubling nature of the animosities makes it difficult to formulate them precisely and to check them justly. They overflow the bounds of reason: all sorts of ancient enemies, individuals and groups become the targets of these ani- 
mosities. Once an investigative committee is started to satisfy these passions, it brings with it so many other advantages such as publicity, advancement, and approbation from more vocal constituents, that it keeps going on its own steam.

The second factor, the fear of disloyalty which might culminate in subversion, is a relatively new one on the scene. It points however in the same direction and gives a certain form to the vague animosities towards the bureaucratic usurpation of legislative power. Whereas earlier fears of revolution were focussed on dissidents outside the government-outcasts of society who would attack the seats of governmental power from the outside-the experience of recent years has given rise to fears and phantasies of the revolutionary seizure of power by persons within the government. The Communist method of subversion, which was illustrated by their interest in the ministries of interior and defense, had its efficacy demonstrated in the Czech coup d'etat in r948. The shock caused by events in Prague combined with the anti-bureaucratic disposition and the exaggerated sensitivity to disloyalty to add heat and fury to investigations into the workings of the administrative branch of the American government. The discovery of some genuine cases of espionage and intended subversion has given such subjective plausibility to these fears that they have now come to seem, to those who shared the more general apprehensions, to justify any accusation.

\section{IV}

It must not be thought that the strong emotions of uneasy legislators are reserved only for bureaucrats, intellectuals, and agents of foreign subversion, etc. Congressmen conducting investigations are not always the friends of the existing economic system or of the "vested interests" of big business. In the main, congressional investigations, even when they are hostile to great economic organizations, usually treat individual business men politely. It is also probably true that in this most recent period where the various categories of the legislator's internal and foreign enemies have preoccupied them, "big business" has been treated rather respectfully. It is not always so however. Congress in its sentiments is disposed to sympathize with the small business man and to look with suspicion on the great organizations. Legislators in the United States are disproportionately of small town origin and their values too are those of the small town society. Big business represents a negation of these values. Moreover in addition to these fundamental sentiments and principles which favor small business, many of the legislator's errands on behalf of 
constituents are conducted for small business men. Not all the grievance which flows from injustice or rebuff is directed toward the bureaucrat. Some of its goes towards big business.

On the other hand big business represents the successful culmination of the aspirations of the small business man; he who sympathizes with the latter cannot withhold some admiration from the former. Many of the great American industrial achievements which make legislators proud of their American nationality are the achievements of "big business men." Their attitude towards big business is therefore ambivalent. Big business is vast, impersonal and often creates hardships for their small business constituents. Moreover it very often works through sophisticated lobbyists whose personal charm and favor do not always eradicate the guilty feeling of having allowed oneself to be seduced by the "vested interests," and do in fact generate guilt for having yielded to their blandishments. As a result of this ambivalence in loyalties to the different strata of the business community, legislative attitudes towards big business are more fluctuating than they are towards bureaucrats, intellectuals and subversives. When the tide turns against the big business man, as it did for instance in the I930's, and they become the objects of investigation, the violence of tone and the acrimonious method of conducting an inquiry can reach the extremes which the investigations of other targets have reached since the Second World War.

In the tense atmosphere of the legislative investigation, where accumulated passions are released against potential or imagined enemies, each accusingly worded question or hostilely intended general statement sets the stage for more bitter accusations and more violent denunciation. The pattern of discourse already too prevalent in American political lifethat a point cannot be made unless it is overstressed and reiterated in the strongest possible terms-has been further developed by congressional investigations and made into the standard currency of American legislative and political argument. Legislators who feel relatively little animosity against their opponents use this language because it has become a convention of their profession or because to be heard in the clamor of sensational words, they too must speak sensationally. It is not only that injustices are done to administrators and private individuals and that the processes of administration, even on the highest levels, are impeded by the way in which congressional investigations are sometimes carried on. The main defect does not lie in the fact that the conduct of the investigative commit- 
tees, which are most unscrupulous in their desire for publicity, discredits investigative committees in general and causes their valuable achievements and outstanding merits to be overlooked. The deeper damage consists in what it is doing to the tone and etiquette of American political life. The tolerance and calm which are necessary for rational discussion of the extremely complicated and difficult alternatives confronting us are greatly diminished by the standards of political discourse which the most vociferous of congressional investigative bodies are establishing. This is a time when it is most desirable and necessary that the older crudities of mind and sentiment should be replaced by dispassionate reflection and carefully measured statement. The tact and self-restraint which are essential to the political life of a democracy are stunted in this atmosphere.

By their disrespect for the proprieties, without which an efficient democratic government cannot function, the reputation of the political profession is further besmirched and the quality of its performance is reduced. The injury which the low prestige of the political career has done to our country has fortunately been neutralized by the sound sense of the mass of the population, and the exceptional devotion to the public good of a small number of morally and intellectually eminent men in each generation. The nature of the tasks facing politicians today however is so taxing to every moral and intellectual resource that the questionable luxury of political savagery can no longer be afforded. Yet the situation is not easily curable. The misbehavior of a significant minority of legislators lowers the esteem in which the professional politician is held. This low esteem is in its turn one of the factors which accounts for the excesses in the conduct of the legislators in investigation and other activities. In a situation which seems much like a vicious circle at least part of the remedy must be sought in greater tactfulness and restraint. It is not too much to hope that if legislators, politicians and citizens can be made more aware of the delicate balance on which the free society rests, some of them will change their behavior and others will no longer support or tolerate practices which are harmful to the democratic system. 